Jurnal Kesehatan Masyarakat

\title{
Social Epidemiology Analysis of Overweight in Toodler at Sukagumiwang Public Health Center Indramayu District
}

\author{
Andy Muharry ${ }^{1 凶}$, Isti Kumalasari ${ }^{1}$ \\ ${ }^{1}$ Program Studi Kesehatan Masyarakat, Sekolah Tinggi Ilmu Kesehatan Kuningan, Indonesia
}

\begin{tabular}{l} 
Article Info \\
\hline Article History: \\
Submitted July 2018 \\
Accepted September 2018 \\
Published November 2018 \\
\hline Keywords: \\
social epidemiology, \\
obesity, toddlers \\
\hline DOI \\
https://doi.org/10.15294/ \\
kemas.v14i2.15279
\end{tabular}

\begin{abstract}
The prevalence of obesity in children has increased from year to year. Patterns and eating behaviors, lack of physical activity and heredity are considered factors causing overweight.The purpose of this study to analyze the social epidemiology of overweight incidence at Sukagumiwang Public Health Center. This research was conducted in 2017 with research subjects being parents of toddlers. The sampling technique is total sampling. This research uses concurrent embedded design. Interviews conducted on parents who have a fat toddler. The questionnaires were distributed to the case and control group of 36 people. The results of research states that socioeconomic status and social capital are not related to the incidence of obesity.Toddlers with obesity have diverse backgrounds. Negative social support and stigma received by toddlers with obesity resulted in psychological impact and less toddler interactions. Toddlers with obesity feel different from other toddlers. Diet by consuming sweetened condensed milk and packaged sweet drinks every day triggers overweight.
\end{abstract}

\section{Introduction}

Obesity is a worldwide health problem often found in many country as result of unbalance between energy intake and consumption (energy expenditures), thus this conserve in form of lipid. The prevalence of overweight and obesity on children in the world increased from $4.2 \%$ in 1990 to $6.7 \%$ in 2010 . Based on Rises Kesehatan Dasar (Riskesdas) in 2013, obtained that the prevalence of obesity on toddler in 2007, 2010, and 2013 based on body height and weight refer to standard anthropometry of toddler from WHO in 2005 was $12.2 \%, 14.0 \%$, and $11.9 \%$ thus nationally the prevalence still higher than global percentage.

Overweight and obesity can be caused by environment factor, even tough the genetic factor is also suspected to contribute yet can not explain the increase of overweight and obesity prevalence. The effect of environment factor, particularly take role through unbalance of eat habit and behavior with physical activity (Quick, 2018). Further Weng et. al. (2012) in a research mentioned the weight of newborn baby, expedite increase of the infant body weight in first year of life and mother smoking behavior during pregnancy is a related factor to overweight on the baby. While breastfeeding behavior is a protective factor against overweight.

So far the etiology of obesity on children only view from clinical and demographic aspect, yet on wider social label variable scope such as socio-economic position, 
distribution of income, race/ethnicity, gender, social network, social capital and community cohesion, work environment, life transition and psycho-affective condition have not been evaluated. Those variables are included in social epidemiology trying to view the social allocation mechanism (social and economic strength) resulting different explanation thus produce health disparity whether good or bad (Berkman et al., 2014).

The Integrated Children Health Service Post (Posyandu) at Sukagumiwang Community Health Service Centre (Puskesmas) Indramayu District on February 2016 revealed 44 toddlers with overweight and obese category of total 376 toddlers (11,7\%). This number became 18 toddlers with overweight and obese category of total 120 toddlers (15\%) on May 2017. This prevalence is considered as a problem that need to be studied from socio epidemiology approach as from clinical etiology had been studied many times. So the researcher interested to study socio epidemiology of overweight toddler incident and analyze related variable with overweight toddler in Puskesmas Sukagumiwang Indramayu District work region.

\section{Method}

This research used combination method with concurrent embedded design. The quantitative research is used to confirm the information obtained through qualitative one. In this model there are primary method (qualitative) and secondary method (quantitative). Primary method is used to obtain primary data and secondary method is used to support the data obtained from primary method. Study design used in the quantitative research is case-control. The instrument of qualitative research is interview as for quantitative research is questionnaire.

The population was all parents in Puskesmas Sukagumiwang work region having overweight and obese toddler. Qualitative sampling was taken purposively. The population of overweight toddlers obtained were 18 children. The sample of quantitative research consisted of case sample and case control taken based on exclusion and inclusion criteria. Inclusion criterias were respondents recorded in posyandu/puskesmas in 2016, still living in
Puskesmas Sukagumiwang work region and nutrition status had been validated by nutrition attendant. As for exclusion criterias were respondent had passed away and moving out district. Number of control sampel was taken with 1:1 composition. Thus total sample in this research are 36 toddlers. Sampling activity taken time on May 2017.

Ther are two phase of analysis which are qualitative research analysis and quantitative research analysis. Qualitative research analysis going through series of transcription process of interview result from audio to written material. Then it is coded, it is categorized to socio epidemiology theme relevant with previous literature overview written before. The cathegorisation result then being mapped in a concept. Quantitative research is used to dig information regarding socio economic status variable and social capital. Data obtained is then analyzed univariately and bivariately by chi-square test.

\section{Result and Discussion}

This research was taken time for two months from May - June 2017. Qualitative data was obtained from 8 informant consisted of 7 parents having overweight toddler and 1 operational nurse serving at Puskesmas Sukagumiwang.

Quantitative date obtained as many as 36 persons consisted of 18 parents having overweight toddlers and 18 parents having normal weight toddlers.

Table 2 indicates proportion of low education level on case group is larger than control group. Meanwhile high education proportion on case group is lower than control group. The statistic test result is $\mathrm{p}$ value $=0.502$ $>0.005$ thus there is no relation between socio economic status and overweight incident on toddler.

Based on above table can be seen the poor social capital proportion on case group is higher than control group. While good social capital proportion on case group is lower than control group. Yet viewing from statistic test result where $\mathrm{p}$ value $=0.310>0.05$ indicates there is no relation between social capital and overweight incident on toddler.

Socio economic status of the parent respondents having overweight toddler are 
Andy Muharry, Isti Kumalasari / Social Epidemiology Analysis of Overweight in Toodler

Table 1. Characteristic of Qualitative Risearch Informant

\begin{tabular}{lllllll}
\hline No & $\begin{array}{l}\text { Informant } \\
\text { Name }\end{array}$ & Age & Work & $\begin{array}{l}\text { Child } \\
\text { Name }\end{array}$ & $\begin{array}{l}\text { Child } \\
\text { BW }\end{array}$ & $\begin{array}{l}\text { Child Age } \\
\text { (Months) }\end{array}$ \\
\hline 1 & Bpk Waw (R1) & 36 & Driver & Naw & 20 & 38 \\
2 & Ibu Tin (R2) & 33 & Store Keeper & Naw & 20 & 38 \\
3 & Bpk Kar (R3) & 42 & Teacher and sale nasi goreng & Ask & 19 & 18 \\
4 & Bpk Ar (R4) & 35 & Social counselor, private teacher, & Ahz & 23 & 40 \\
& & & grocery store owner & Ahz & 23 & 40 \\
5 & Ibu En (R5) & 30 & Insurance employee & Ilh & 30 & 36 \\
6 & Ibu Kay (R6) & 39 & Village chief's wife, farmer & Gal & 11,5 & 12 \\
7 & Ibu Rok (R7) & 32 & Fried food seller & - & - & - \\
8 & Ibu Ad (R8) & 38 & Operational Nurse & & & \\
\hline
\end{tabular}

Table 2. Bivariate Test Result of Socio Economic Status and Toddler Overweight Incident

\begin{tabular}{llll}
\hline SSE Cathegory & \multicolumn{2}{l}{ Toddlers Status } & Total \\
\cline { 2 - 3 } & Case & Control & \\
\hline Low & $11(61 \%)$ & $9(50 \%)$ & $20(55,6 \%)$ \\
High & $7(43,8 \%)$ & $9(50 \%)$ & $16(44,4 \%)$ \\
Total & $18(100 \%)$ & $18(100 \%)$ & $36(100 \%)$ \\
$p=0,502$ & & & \\
\hline
\end{tabular}

Table 3. Bivariate Test Result of Social Capital and Toddler Overweight Incident

\begin{tabular}{llll}
\hline Social Capital Cathegory & \multicolumn{2}{l}{ Toddler Status } & Total \\
\cline { 2 - 3 } & Case & Control & \\
\hline Poor & $12(66,7 \%)$ & $9(50 \%)$ & $21(58,3 \%)$ \\
Good & $6(33,3 \%)$ & $9(50 \%)$ & $15(41,7 \%)$ \\
Total & $18(100 \%)$ & $18(100 \%)$ & $36(100 \%)$ \\
$p=0,310$ & & & \\
\hline
\end{tabular}

vary. Interviewed respondents has various work background which are Kuwu (Village Chief), teacher, driver, business owner and fried food seller. Interviewed respondents have high school and university education level as on quantitative research, the education level background of parents having overweight toddler are nearly half of them (44\%) have elementary education and more than half (50\%) have high school education level.

As many as $61 \%$ of overweight toddlers come from families with low socio economic status, while on control group the proportion of family socio economic status is equal between low and high. The quantitative research result stated the socio economic status does not related with overweight incident on toddler in Puskesmas Sukagumiwang work region $(\mathrm{p}=0.502)$. Variables used in determining the socio economic status based on Bistok Saing method consist of education, work, income, number of family member, house ownership status, the building condition of the house, wealth goods and drinking water source. There is no relation between economical status of a family with having overweight toddler. Research result shows whether low or high socio economic status in case group as well as control group has similar characteristic.

This is aligned with Mappeboki (2009) research stating there is no relation between socio economic status with nutrition giving 
pattern on obese toddler. In same research stating only mother's last education and mother's work related with nutrition giving pattern on obese toddler. Different result mentioned by Myrnawati \& Anita (2016) stating socio economic status related with life style and meal giving pattern on early child education (PAUD) in Semarang and also directly affect PAUD Children nutrition status. This is also mentioned by Pahlevi (2012) that family income is one of factor highly affect children nutrition factor.

Allinformant are Javanese and Indramayu local residents. All informant also living on owned house. Interested phenomenon found in this research is all informant interviewed and the spouse (father and mother) that are Javanese generally like sweet taste meal. Packaged sweet drink is common serving to guest. This is admired by the Puskesmas nurse (R8).

\begin{abstract}
"That was... during the data collection ummm... yesterday when we conducted the health family survey if I was not mistaken... that's when we got bottles of sweet drink... merely a grocery shop... just like now... how many bottles have you got during these interviews (R8)"
\end{abstract}

Packaged sweet drink become children's favorit as been said by R2

“...Well they asked for cold packaged tea.... sometime 3-4 packages are consumed...(R2)"

Ethnicity has relation with children nutrition status. Nutrition socio culture relationship in meal choice depend on local culture norms. Ethnical culture background or ethnicity can affect belief system, principle, and one behavior that by the end will affect parent's strategy or decision in term of meal pattern and proper quantity of food for their children (Pavilianingtyas, 2017). Culinary tradition of a region is different with the other. In a community, serving the meal is depended on family meal pattern coming from same ethnic and religion group and same socio economic level. Meal habit also related with group member social network in serving kind of food in the family. Meal serving habit is also affected by formal education of the person preparing it (Trimanto, 2008).

Puntam in Berkman et. al. (2014) mentioned social capital is community characteristic consisting of social organization, community participation, norm reciprocity, trust feeling between community member in order to facilitate cooperation to reach common benefit. Social capital is a mechanism and relation between trust, norm and network in social arrangement on a community.

Quantitative research result indicates social capital is not related with overweight incident on toddler in Puskesmas Sukagumiwang Indramayu District work region $(\mathrm{p}=0,310)$. This is different with research by Trimanto (2008). The research which was taken place on Sragen indicated significant relation between social capital with toddler nutrition status on Sragen District $\left(\mathrm{x}_{2}=89,89\right.$, $\mathrm{p}=0,000$ ).

Different result can be understood due to empirical research does not give consistant result regarding effect of social capital to health. All is depended on the region characteristic condition. According to Lynch et. al. (2000) and Edmondson (2003) in Trimanto (2008), social capital effect to health status is depended on social context in the region. The component of social capital react with social contact causing variation of social capital effect to healt status.

Indicator used to measure social capital are parent and community perception regarding overweight on toddler. Research result indicates respondent's participation in posyandu activity is quite well. Interpersonal interaction in posyandu activity generate community perception or belief that a fat child is a health child This is a thing that believe by most of the people in the community from generation to generation. The assumption intrique every parent having toddler try to reach the "health" standard belong to the families and communities around. It can be seen from participation to come to posyandu to have their children health and monitor the children growth and development. This is aligned with research by Dhyanaputri et al. (2011) mentioning there still many mother consider obesity is a good thing for her child 
instead a health problem.

Posyandu activity on Sukagumiwang Sub District is well going. Community participation is quite good as said by responden.

"It's so crowded here when Posyandu
was held.... Its all here... the cadre was
active... Just one or two residents like
Ahz (child of Mr. Ar/R4) that never
joined... one or two times maybe
they came... oftenly I entrusted to the
neighbour when there was vitamin
distribution. Two months ago the
brother came... also the cousins... I
just then find out how fat he is. Well
the family is not too friendly... rarely
sosialized with the neighbour...(R8)"

Research by Rahayu et. al. (2014) indicated several social capital element relating with toddler nutrition status like active participation of the community in social organization. The involvement of community member as Posyandu cadre is an indicator of community active role in social organization to assist in solving nutrition and health problem in the community.

There are two form of social capital which are structural and cognitive. Structural form refers to social network and social association, while cognitive form refers to subjective element such as trust and norm of reciprocity. Social capital is important due to it facilitate the community to solve collective problem easily, encourages the community to help each other and improves community awarenes through in the same booat feeling. The network underlying social capital also playing role as information channel highly support to achieve the success (Berkman et al., 2014).

Social cohesion refers to connected and solidarity level between groups in the community. Cohesive community is marked by the existance of common moral support, does not make an individual to stand over owned resources. Yet it is family or community support through motivation giving to the individual having problem (Berkman et al., 2014). Cohesive community is one rich of social capital like interpersonal reliance level, reciprocity norm and help each other that become resources for an individual to do collective action Suryanto et al. (2014) in the research stated social support and family role can affect growth and development of a child that finally will affect nutrition status.

Social cohesion and social capital together form the social support. In case of overweight and obesity oftenly given negative image, the stigma addressed to both child and parent. As mentioned by following respondent:

"Yes, many... my neighbour said, when my child was as old as yours, the weight was not like this (R2)"

Other respondent (R3) also said not only the neighbour, different things said by another

\footnotetext{
"Not only the neighbour, a passing by oftently said. My child after took a bath sometime ran outside the house, one time someone step off from motocycle and take a picture of my child. Probably prevent me from being upset if comment about my child overweight so the person said "What a health child" (R3)
}

Different result can be seen on under nutrition and poor nutrition. Social culture on village community gives great social support and contribute to toddler nutrition status in the community. Research by Runingsari (2014) on Pekalongan showed social supports supporting toddler nutrition status are emotional, instrumental, informational and esteem support came from family, neighbour, friend, community leader, political leader, government official and community organization. Emotional support like careness and attention to the toddler condition, instrumental supports in form of money, material and merit for daily life, informational support comes through information, advise or guidance regarding toddler caring and parenting. Esteem support come in form of positive statement or acknowledgement on parenting.

Stigma and negative support from community cause the toddler to have less socialization and less interaction with environment. Toddler still play with peer yet quite restricted as said by respondent 3 (father 
of toddler Az).

"I understand, when people talk about it he laught yet cover his face with hand due to shy (R3)"

Toddler also feel under confidence while playing with peers.

"While playing with the peers he tends to give in, like when the toy was taken he didn't try to keep it. Event if being hit by the peer he did not hit back (R3)."

Self of under confidence results the emerge of psychological barrier on the child thus feel different from other children.

"....When being told "don't be that overweight" he replied "let me be" then he will drink a lot of milk (R1)"

Ridicule also addressed to one toddler, said as "not biological child" of the parent due to different posture with the sibling.

"Ilham only play with his brother.... oftenly shy... even though eat in same portion like his cousins yet he become overwheight....... (R6) ....sometime one said "you are not Mrs. Kuwu son"... it's so rough...(R8)"

Among the respondent family (R4 and R5) known as exclusive ones. Their child only attended Posyandu event twice. The family has been well known as rich and respected by the neighbour thus rarely interact in the neighbourhood. This is mentioned by the respondent.

"My child never play outside of our house... going out once a week... go to our relative... also for sightseeing.... other than the moment only play in the house with the older cousins... whose house just in front of ours... or play bicycle inside...(R4)"

Individual factor asked related with food intake and physical activity of the toddler. Interview result indicates toddlers every day routinely consume sweetened condensed milk, powder milk and packaged sweet drink.

“...snacking usually milk, ice cream, sometime chiki snack balls. He likes sweet tea but not home made. He wants cooled packaged ready to drink tea... sometime even consumes 3-4 packages...(R2)"

“...Drink milk, indomilk......... until six packages of it, one day one pack contained six packages so six packages until night. Because two packages are consumed with older brother. The older brother still use rubber nipple... (R3)"

Toddler does not like fruits (R1) and vegetables $(\mathrm{R} 1, \mathrm{R} 2)$.

"its difficult to make him consume vegetables or fruits.... does not like it at all, once ate avocado and dragon fruit, just a little bit (R1)"

Other respondent (R2) ought to work as state teacher and own side business selling fried rice, told that have difficulty to take care all three children alone. His wife was having migrant worker training thus he can't put attention to the children meal pattern, including the habit of one child to consume instant coffee daily.

"Perhaps I do mistake because when I drink coffee my child use to ask so I gave. So the coffee is divided onto two portions for my child.... (R3)"

Food and nutrition problem are elaborate problem caused by various factors related each other, one of the factor is food consumption. According to Park et al. (2005), among those factors are socio culture, ecology, demography and life style. Interaction of the various factors then form a community meal habit. The meal consumption habit of a region oftenly related with geographic position. Since early 1980s, economic globalization in developed countries had emerged change of diet pattern and choice of meal. Processed and fast food easily find on the grocery shops around. The people generally in developed countries tend to choose energy 
rich diet, high plant oil and high fat (Witkowski, 2007, Bhurosy \& Jeewon, 2014).

From a research by Mistry and Puthussery (2015), risk factors of obesity on an individual mainly are lack of physical activity, long time spent to watch TV or play computer game and oftenly consume fast/junk food. Next Setiyaningsih et al., (2016) mentioned unhealthy food can increase risk of obesity. Toddler consume unhealthy food $>32$ times / week has risk 4.26 times higher to be obese. Kinds of unhealthy food commonly consumed are full cream milk, western fast food and sweet drink. Milk consumption $>15$ times/week increase risk of obesity 3.83 times. Consumption of western fast food $>5$ times/week and sweet drink $>8$ times/week increase risk of obesity 2.4 times and 4.14 times each. Parent education related with family economic status level and affect the quantity and quality of food consumed by the children. The higher the education level, then the higher the income so there will be convenience in buying and consuming tasty and expensive food containing high energy like western fast food. Next Istiqomah et al. (2014) also mentioned toddler consuming fast food has risk 9 times higher to obese compare to toddler rarely consuming it. According to Kartiningrum (2013) the frequence of obesity can be decreased when the parent, particularly the mother can do diet management specificly high calorie diet sourced from carbohydrate and fat and by motivate the toddler to have more physical activities together with other family member.

\section{Conclussion}

All respondents come from Java ethnic and are local residents of Sukagumiwang. Status of socio economic and social capital indicate no relation with overweight incident on toddler. Social capital reflected from parent and community perception that overweight is health affect parent's cognitive aspect in form of concern to toddler growth and development. This condition trigger the parent to always try to fullfill food demand of the toddler so that the toddler is seen as a health child by community. The existance of individual factor having habit to consume sweet packaged drink can increase the risk of overweight. Negative stigma is oftenly addressed to overweight toddler and parent causing the toddler become less socializing and interacting with the environment.

\section{Acknowledgement}

This research conducted by support and assistance from many party. Therefore we would like to acknowledge Kementrian Riset Teknologi and Pendidikan Tinggi that have fund this research. Also we would like to thank Research Institute of Stikes Kuningan, all lectured coleagues and staffs, Indramayu District Government and our beloved family.

\section{References}

Berkman, L.F., Kawachi, I., \& Glymour, M.M., 2014. Social epidemiology, Oxford University Press.

Bhurosy, T., \& Jeewon, R., 2014. Overweight and Obesity Epidemic in Developing Countries: A Problem with Diet, Physical Activity, or Socioeconomic Status?. The Scientific World Journal, 20147.

Dhyanaputri, I.G.S., Hartini, T.N.S., \& Kristina, S.A., 2011. Persepsi Ibu, Guru dan Tenaga Kesehatan Tentang Obesitas pada Anak Taman Kanak-kanak. Berita Kedokteran Masyarakat, 27(1), pp.32.

Istiqomah, A., Sundari, S., \& Wulandari, H.R., 2014. Faktor-Faktor Yang Mempengaruhi Obesitas Pada Balita. Jurnal Ilmu Kebidanan Akbid Ummi Khasanah, 1(1).

Kartiningrum, E.D., 2013. Analisis Kejadian Obesitas Pada Balita di Posyandu Pademonegoro Kecamatan Sukodono Kabupaten Sidoarjo. Jurnal Ilmiah Kesehatan Medical Majapahit, 5(2), pp.1-103.

Mappeboki, S., 2009. Hubungan Karakteristik Sosial Ibu dengan Pola Pemberian Nutrisi terhadap Balita Obesitas di Wilayah Kerja Puskesmas Mamajang. Journal Media Gizi pangan, 7(1), pp.155-61.

Mistry, S.K., \& Puthussery, S., 2015. Risk Factors of Overweight and Obesity in Childhood and Adolescence in South Asian Countries: a Systematic Review of the Evidence. Public Health Journal, 129(3), pp.200-209.

Myrnawati., \& Anita., 2016. Pengaruh Pengetahuan Gizi, Status Sosial Ekonomi, Gaya Hidup dan Pola Makan Terhadap Status Gizi Anak (Studi Kausal di Pos PAUD Kota Semarang Tahun 2015). Jurnal Pendidikan Usia Dini, 10(2), pp.213-232.

Pahlevi, A.E., 2012. Determinan Status Gizi Pada Siswa Sekolah Dasar. Jurnal Kesehatan Masyarakat, 7(2), pp.116-120.

Park, S.Y., Murphy, S.P., Wilkens, L.R., Yamamoto, J.F., Sharma, S., Hankin, J.H., Henderson, B.E., \& Kolonel, L.N., 2005. Dietary Patterns 
using the Food Guide Pyramid Groups are Associated with Sociodemographic and Lifestyle Factors: The Multiethnic Cohort Study. The Journal of nutrition, 135(4), pp.843-849.

Pavilianingtyas, A., 2017. Faktor Agen, Pejamu, dan Lingkungan Kejadian Obesitas Pada Anak Usia 5-6 Tahun. Jurnal Gizi Indonesia (The Indonesian Journal of Nutrition), 5(2), pp.105-111.

Quick, V., 2018. Clustering of Obesity-Related Risk Behaviors among Families with Preschool Children Using a Socioecological Approach: Cross-Sectional Study. Journal of Medical Internet Research, 20(4), pp.1-1.

Rahayu, T., Budiono, I., Hunnirun, P., Tornee, S., \& Hansakul, A., 2014. Social Capital and Nutritional Status of Child Under 5 Years in Rural Indonesia and Thailand. Jurnal Kesehatan Masyarakat, 10(1), pp.88-95.

Runingsari, T., 2014. Kontribusi Unsur Social Suport Dalam Mendukung Status Gizi Balita (Studi Kasus di Desa Sangkanjoyo Kecamatan Kajen Kabupaten Pekalongan). Universitas Negeri Semarang.

Setiyaningsih, Y.E., Nurwanti, E., \& Pratiwi, A.M., 2016. Konsumsi Unhealthy Food Sebagai Faktor Risiko Obesitas Pada Balita di
Puskesmas Jetis, Kota Yogyakarta. Jurnal Gizi dan Dietetik Indonesia, 3(3), pp.7.

Suryanto, S., Purwandari, H., \& Mulyono, W., 2014.

Dukungan Keluarga Dan Sosial Dalam

Pertumbuhan Dan Perkembangan Personal

Sosial, Bahasa Dan Motorik Pada Balita Di

Kabupaten Banyumas. Jurnal Kesehatan Masyarakat, 10(1), pp.103-109.

Trimanto, A., 2008. Hubungan Antara Tingkat Pendidikan Ibu, Pendapatan Keluarga, dan Modal Sosial Dengan Status Gizi Anak Balita di Kabupaten Sragen. Magister Kedokteran Keluarga, Universitas Sebelas Maret Surakarta.

Weng, S.F., Redsell, S.A., Swift, J.A., Yang, M., \& Glazebrook, C.P., 2012. Systematic Review and Meta-Analyses of Risk Factors for Childhood Overweight Identifiable During Infancy. BMJ Journals Archives of Disease in Childhood, 97(12), pp.1019-1026.

Witkowski, T.H., 2007. Food Marketing and Obesity in Developing Countries: Analysis, Ethics, and Public Policy. Journal of Macromarketing, 27(2), pp.126-137. 